\title{
Editorial \\ Capitalismo avanzado y economía social
}

\author{
Javier Divar Garteiz-Aurrecoa \\ Catedrático Emérito de la Universidad de Deusto
}

doi: http://dx.doi.org/10.18543/dec-17-2021pp15-18

\section{Los mercaderes}

Las actividades mercantiles son esenciales en la vida en sociedad, procuradoras de bienes y servicios. Profesiones necesarias y útiles.

Pero su vieja imagen cercana a la codicia y aún a la avaricia, hizo que a lo largo de los tiempos se menospreciaran como poco dignas, inapropiadas para la nobleza, por tanto.

Así los mercaderes se fueron estableciendo como una clase social singular, por debajo de los señores y del alto clero.

Algunos, enriquecidos, fueron aceptados por la nobleza como aportantes económicos, si bien siempre sospechosos de bastardía social.

Roma les reconoció como clase jurídica, estableciendo para ellos los «Pretores de los Mercados», como jurisdicción mercantil que aplicó el ius civile con carácter especial.

La caída del Imperio Romano llevó al viejo mundo a una depresión económica que se mantuvo durante toda la Alta Edad Media.

Pero en la Baja Edad Media renacerá el esplendor del comercio, singularmente del tránsito marítimo de mercancías. Ese auge de la mercantilidad, que había iniciado la República Serenísima de Venecia, continuó con los puertos del norte del Mar Tirreno, instaurando los Consulados de Comercio, creadores del Derecho Mercantil mediante sus Ordenanzas.

El viejo estigma de profesión menor, cuna del pecado de avaricia, será redimido por la llegada de la Reforma Protestante, que consideró el comercio como una profesión noble, incluso a los ojos de Dios («burgueses gentilhombres»).

Al fin, el liberalismo, con la triunfante y extendida Revolución Francesa, los elevará a clase dominante. Además, la Codificación (Código 
de Comercio Napoleónico) establecerá el carácter general de su Derecho, facilitando el triunfo del mercantilismo.

\section{El capitalismo}

De entonces a hoy, la acumulación de plusvalías y la constitución y regulación jurídica de las sociedades anónimas (superando las antiguas sociedades personalistas), facilitará la inversión de capitales mediante acciones de libre circulación. La extensión del modelo nos llevará al Capitalismo como sistema económico y social imperante.

Las Bolsas de Comercio facilitarán complementariamente el movimiento de títulos, la inversión societaria y la especulación financiera.

Aunque no suele hacerse hincapié en ello, el capitalismo no es sólo un sistema económico. Es un sistema social. Una cultura, pues sus valores y principios terminan extendiéndose a toda la comunidad.

Pero el sistema deja al margen a pobres y trabajadores, puesto que la plusvalía de los negocios es para el capital.

Sin embargo, las clases populares aceptan su marginación si pueden satisfacerse mediante un consumo de mantenimiento. Complementariamente, mejoras en los derechos sociales paulatinamente establecidas por la legislación, van haciendo que el sistema cambie (para permanecer esencialmente igual) y sea soportado por la población.

Pero la cultura capitalista tiene notables resultancias sociales. Una de ellas es la apreciación generalizada de lo económicamente rentable como lo único de utilidad, lo que hace perder valor a toda actividad que no produzca beneficios económicos.

Ello alcanza incluso a los estudios calificados como «poco prácticos», que son, claro está, todos los que no pueden ser explotados directamente por la maquinaria económica. Lo que acaba conduciendo a una sociedad menos formada y poco crítica.

Otra consecuencia de la cultura capitalista es el individualismo, derivado de la dura competitividad, como filosofía mercantil.

Y ante el dios de la competitividad, la solidaridad aparece como una debilidad, cuando debiera ser una preferencia social. El resultado del individualismo es que en las sociedades avanzadas la cercanía entre las personas sea cada vez menor, creciendo por el contrario el interés propio y el egoísmo.

Consecuencia evidente del sistema es también el consumismo desaforado. Como se precisa para el mantenimiento del mismo unas elevadas producciones, lógicamente son necesarios los consumos masivos. 
Esos consumos son incentivados por las grandes divisiones de la publicidad comercial, maestras en la creación de necesidades (incluso supérfluas).

Para facilitar el consumo y aumentar los beneficios se busca el bajo coste en la producción, lo que se consigue con materias primas y mano de obra baratas (explotación del Tercer Mundo).

El daño a la Naturaleza por la acumulación de residuos es enorme, ante la salvaje política del «usar y tirar» consumista.

Pero además hay que contar con el daño psicológico. Muchas personas en las naciones avanzadas necesitan un consumo constante para sentirse realizadas. La propaganda comercial les ha inducido a creer que necesitan cosas para ser felices. No para cubrir sus necesidades, sino para atender a sus deseos inducidos.

La científica (y machacona) publicidad comercial les ha imbuido imágenes de un paraíso de luz y de color, que de no alcanzarlo terminan en frustraciones.

Al final el tener parece mucho más benefactor que el ser, puesto que a muchos les resulta más grato que el pensar.

Además el consumo implica un nivel social. No puedes pertenecer a una clase si no adquieres el automóvil correspondiente o la casa soñada o los cachivaches electrónicos propios del nivel. Y para alcanzar un nivel superior debes tener un consumo superior, pues el sistema va estableciendo niveles que acreditan la calidad social de las personas, que sufren si no los alcanzan.

Pero la pregunta clave es: ¿hay alternativa económica al capitalismo?

Una respuesta evidente es el doble sistema de algún país comunista, con el paradigma de China. Capitalismo tolerado dentro de una república popular. Pero el resultado final es la creación de una élite capitalista que reproduce las resultas del capitalismo puro.

\section{El cooperativismo}

Otra alternativa, mucho más eficiente, aunque viva en la sombra ocultada por el fulgor del capitalismo, es la del movimiento cooperativo.

Al igual que el capitalismo, el cooperativismo tiene su origen en la Reforma Protestante, pero mientras que aquél procede de la influencia religiosa de la burguesía mercantil, el cooperativismo tiene su origen en el reformismo religioso de los cuáqueros en Holanda e Inglaterra. El regreso a los orígenes del cristianismo con las comunidades de la ayuda mutua. 
Los cuáqueros practicaban en sus comunidades («Las Sociedades de Amigos») la ayuda colectiva a los necesitados.

En el ámbito económico crearon, según sus propias palabras, «colonias o repúblicas cooperativas» de trabajo y consumo, para alcanzar «la felicidad de los pobres» (Plockboy). Esas colonias fueron el antecedente del movimiento cooperativo.

En un primer momento cooperativismo y mutualismo se confunden, en el objetivo finalista de la autoayuda, históricamente propio de las comunidades campesinas.

Los viejos sistemas de tierras y bosques comunales, así como la economía colaborativa de los campesinos, estaban muy extendidos en todo el mundo.

Cuando se produjo la primera industrialización, esa población campesina emigró a las ciudades manufactureras, llevándose consigo su cultura popular. Por eso aquel proletariado se afilió gustoso a las sociedades de socorros mutuos.

Esa es la razón por la cual la considerada como la primera cooperativa del mundo, la de Rochdale (Manchester, 1844), inspiró sus estatutos en la Mutua General de Socorros de Manchester).

A partir del reconocimiento registral de los estatutos de Rochdale se desarrolla el movimiento cooperativista, que pronto vio reconocida su peculiar forma jurídica por la legislación (Inglaterra, Francia, Alemania).

La característica principal del cooperativismo es su carácter democrático, participativo. Los socios tienen en las cooperativas un voto unipersonal, con independencia del capital suscrito o de su categoría laboral.

Con esa base las cooperativas se convierten en la punta de lanza de la democracia económica, completado el voto unipersonal con el derecho de todo socio a ser elegido como miembro de los órganos societarios.

La otra característica fundamental de las cooperativas estriba en que el beneficio («excedente», en términos cooperativos) no se reparte por cuotas de capital, sino por las prestaciones personales del socio a la cooperativa.

Actualmente, las cooperativas comandan la llamada Economía Social, término acuñado por la cultura económica francesa para referirse a toda forma de empresa cercana a los principios y valores cooperativos.

Al fin, la alternativa cooperativa se presenta como una formulación económica singular, esperanza de un mundo mejor. 


\section{Derechos de autor}

http://dec.revistas.deusto.es/

La revista Deusto Estudios Cooperativos es una revista de acceso abierto lo que significa que es de libre acceso en su integridad inmediatamente después de la publicación de cada número. Se permite su lectura, la búsqueda, descarga, distribución y reutilización legal en cualquier tipo de soporte sólo para fines no comerciales y según lo previsto por la ley; sin la previa autorización de la Editorial (Universidad de Deusto) o el autor, siempre que la obra original sea debidamente citada (número, año, páginas y DOI si procede) y cualquier cambio en el original esté claramente indicado.

\section{Copyright}

The Deusto Journal of Cooperative Studies is an Open Access journal which means that it is free for full and immediate access, reading, search, download, distribution, and lawful reuse in any medium only for non-commercial purposes, without prior permission from the Publisher or the author; provided the original work is properly cited and any changes to the original are clearly indicated. 